УдК 617.5-089.844

DOI 10.11603/2414-4533.2018.3.9437

○Ю. Ф. КОШАК ${ }^{1}$ Ю. Ф. САВЕНКОВ ${ }^{2}$

ДВН3 “Тернопільський державний медичний університет імені І. Я. Горбачевського МОЗ України” К3 “Тернопільський обласний протитуберкульозний диспансер” 1

КЗ “Дніпропетровське обласне клінічне лікувально-профрілактичне об'єднання “Фтизіатрія” дОР”2, Дніпро

\title{
Діагностика та хірургічне лікування поєднаних форм туберкульозу і раку легень
}

\begin{abstract}
Мета роботи: представити перший в Україні аналіз ефективної ранньої діагностики та хірургічного лікування хворих із поєднаними формами легеневого туберкульозу та недрібноклітинного раку легень із застосуванням стерно-медіастинального хірургічного доступу; підвищити ефективність хірургічного лікування хворих із поєднаними формами легеневого туберкульозу та недрібноклітинного раку легень.

Матеріали і методи. Проведено вибірку пацієнтів, ретроспективний аналіз 91 випадку хворих із поєднаними формами легеневого туберкульозу і раку легень, які проходили лікування у протитуберкульозних диспансерах, хірургічних відділеннях різних регіонів України.

Результати досліджень та їх обговорення. Проаналізовано морфологічні особливості поєднаних форм легеневого туберкульозу, асоційованого із недрібноклітинною формою раку легень у групах порівняння, які вивчали ретроспективно. Показано провідний вплив легеневого туберкульозу на хірургічне лікування хворих із поєднаними формами туберкульозу і раку легень у групах порівняння. Встановлено збільшення трирічної виживаності в пацієнтів основної групи, що свідчить на користь активної ранньої діагностики, хірургічної тактики стерномедіастинального доступу та застосування при цьому більш радикальної системної повної білатеральної лімфодисекції в межистінні.
\end{abstract}

Ключові слова: поєднані форми туберкульозу та недрібноклітинного раку легень; діагностика; хірургічне лікування; стерномедіастинальний доступ; повна білатеральна лімфодисекція в межистінні.

Постановка проблеми і аналіз останніх досліджень та публікацій. Сьогодні туберкульоз легень (ТБ) є головним джерелом помилок у діагностиці раку легень (РЛ), в тому числі і недрібноклітинної форми раку легень (НДКРЛ), яка $є$ перспективною в хірургічному лікуванні та вилікуванні. Рак легень на тлі туберкульозу в 60-70 \% хворих встановлюють при запущених IIIA-B - IV стадіях, коли хірургічне лікування уже не $\epsilon$ можливим. Частота поєднаних уражень туберкульозу і раку легень $€$ досить розбіжною, за різними літературними джерелами поєднання складає від 3 до 18 \% усіх випадків раку легень. Ефективність ранньої діагностики поєднаних форм не перевищує 67,9 \%. Застосування хірургічного етапу в комплексному лікуванні хворих із поєднаними формами туберкульозу і раку легень покращує підсумкові результати лікування на 10 $20 \%$. Проте на сьогодні ще не вирішені питання ранньої діагностики та адекватної хірургічної тактики стосовно радикального лікування пацієнтів із поєднаними формами туберкульозу та раку легень, не розроблено методик оперативних резекційних втручань та медіастинальної лімфодисекції у таких пацієнтів. Таким чином, вивчення та розробка ранніх методів сучасної діагностики та методів ефективного радикального хірургічного лікування хворих із поєднаними формами туберкульозу та раку легень $є$ надзвичайно актуальним завданням торакальної хірургії та онкології.
Мета роботи: підвищення ефективності хірургічного лікування хворих із поєднаними формами туберкульозу і раку легень шляхом удосконалення переопераційного діагностичного алгоритму та застосування стерно-медіастинального доступу для резекції легені. Відповідно до мети дослідження було поставлено такі завдання:

- Встановити причини незадовільних результатів хірургічного лікування хворих із поєднаними формами туберкульозу та раку легень від застосування стандартних хірургічних методик.

- Оцінити діагностичні можливості стандартних методів діагностики та розробити оптимальний діагностичний алгоритм при підозрі на рак легень у пацієнтів із легеневим туберкульозом.

- Виявити гістоморфологічні особливості ураження легень і лімфатичних вузлів середостіння у хворих із поєднаними формами туберкульозу та раку легень.

- Розробити операційно-технічні методики хірургічного лікування поєднаних форм туберкульозу та раку легень із застосуванням стерно-медіастинального доступу.

- Провести порівняльний аналіз ефективності хірургічного лікування поєднаних форм туберкульозу та раку легень в основній групі та групі порівняння.

Матеріали і методи. Проведено ретроспективний аналіз історій хвороби 91 пацієнта, які 
проходили лікування у протитуберкульозних диспансерах, хірургічних відділеннях різних регіонів України. Основну групу склали 38 (28,3%) хворих, яким застосовували методики комплексної ранньої діагностики, які ми удосконалили, включно спіральну комп’ютерну томографію органів грудної клітки (CKT) з контрастуванням, відеоторакоскопію (VATS) з біопсією лімфатичних вузлів кореня легені та середостіння, а також розроблені нами хірургічні методики лобектомії та пневмонектомії з повною білатеральною лімфа- денектомією із застосуванням стерномедіастинального доступу. Результати лікування оцінювали проспективно. У групу порівняння увійшли 53 (71,7 \%) пацієнти, яким застосовували стандартні методи діагностики та радикальне хірургічне лікування із використанням стандартної бокової торакотомії та стандартної реґіонарної лімфодисекції. Результати лікування в даній групі оцінювали ретроспективно. Поділ хворих за віком і статтю в обох групах спостереження наведено в таблиці 1.

Таблиця 1. Поділ пацієнтів груп порівняння за віком та статтю (M+m) \%

\begin{tabular}{|c|c|c|c|c|c|c|c|c|c|c|}
\hline \multirow{3}{*}{ Стать } & \multicolumn{5}{|c|}{ Основна група (n=38) } & \multicolumn{5}{|c|}{ Група порівняння (n=53) } \\
\hline & \multicolumn{4}{|c|}{ BiK } & \multirow[b]{2}{*}{ Усього } & \multicolumn{4}{|c|}{ Вiк } & \multirow[b]{2}{*}{ Усього } \\
\hline & $>45$ & $\begin{array}{c}46- \\
55\end{array}$ & $\begin{array}{c}56- \\
65\end{array}$ & $\begin{array}{c}66- \\
75\end{array}$ & & $>45$ & $\begin{array}{c}46- \\
55\end{array}$ & $\begin{array}{c}56- \\
65\end{array}$ & $\begin{array}{c}66- \\
75\end{array}$ & \\
\hline Чоловіки & 1 & 2 & 29 & 2 & $34(89,5 \pm 1,8) \%$ & 1 & 1 & 44 & 1 & $47(88,7 \pm 1,2) \%$ \\
\hline Жінки & - & - & 3 & 1 & $4(10,5+2,1) \%$ & 1 & 2 & 2 & 1 & $6(11,3+2,4) \%$ \\
\hline Усього & 1 & 2 & 32 & 3 & 38 (100\%) & 2 & 3 & 46 & 2 & $53(100 \%)$ \\
\hline
\end{tabular}

Ефективність безпосередніх результатів оцінювалася на підставі вивчення та порівняння кількості інтраопераційних та післяопераційних ускладнень та їх видів, причин післяопераційної летальності.

Ефективність віддалених результатів оцінювали на підставі клінічного лікування, прогресування туберкульозу та онкологічного процесу (середня тривалість життя, відсоток рецидивів пухлинного процесу), смерті від туберкульозу та раку.

Проведений аналіз клінічних груп хворих за віком, статтю, клінічними категоріями туберкульозу, локалізацією та стадією раку легень, загальним станом, показниками спірографії, ЕКГ, фібробронхоскопії та супутньою патологією був репрезентативним.

3 метою вирішення клінічної оцінки стандартних діагностичних методик виявлення раку легень у хворих із туберкульозом був проведений ретроспективний аналіз 78 історій хвороб туберкульозу та раку легень. 3’ясувалося, що ретельне вивчення скарг дозволило запідозрити появу пухлинного процесу лише у 69,2_2,9 \% пацієнтів $(\mathrm{p}<0,05)$. У решти хворих скарги були відсутні, або мали незначне клінічне значення. Вони не були важливим діагностичним алгоритмом для ранньої діагностики поєднаних форм туберкульозу та раку легень. Об’єктивне обстеження пацієнтів також не мало суттєвої діагностичної цінності. При проведенні спіральної КТ без контрастного підсилення вдалося виявити характерні ознаки центрального раку лише у $(71,8 \pm 1,9)$ \% пацієнтів та у $(82,6 \pm 1,3) \%$ хворих з периферичною пухлиною. Діагностична цінність СКТ при локалізації пухлини в зоні метатуберкульозних змін не перевищувала 50 \%. 330 пацієнтів, яким було виконано СКТ органів грудної порожнини, у 6 (20 \%) за результатами післяопераційного дослідження діагностовано метастази в медіастинальні лімфатичні вузли. Помилкове заключення про туберкульозний характер змін при наявності метастазів раку спостерігалося у 57,8 \% випадків. На нашу думку, низька діагностична цінність СКТ при діагностуванні метастатичного ураження регіональних лімфовузлів пов’язана 3 неможливістю відрізнити туберкульозне та пухлинне ураження. За нашими даними, лише у 67,9 \% хворих рак був вірогідно діагностований своєчасно, та ці пацієнти підлягали радикальному хірургічному лікуванню.

Результати досліджень та їх обговорення. Серед груп хворих, які вивчали, переважали пацієнти віком від 55 до 65 років: 32 (84,2+1,2) \% хворих основної групи та $46(86,8 \pm 1,4)$ \% групи порівняння. Середній вік хворих основної групи склав $(59+1,6) \%$ років, групи порівняння - $(61,5 \pm 1,8) \%$ років $(\mathrm{p}<0,05)$. Поєднання локалізації туберкульозного та пухлинного процесів у межах однієї частки легені спостерігали в більшості пацієнтів - у 24 (63,1 \%) основної та у 28 (52,8 \%) групи порівняння (табл. 2).

Анатомічні форми раку легень в обох групах спостереження були представлені як периферичні - у 26 пацієнтів (68,4 \%) основної групи, 34 (64,1%) групи порівняння, так і центральним - у 
Таблиця 2. Локалізація раку легень у групах спостереження (M+m) \%

\begin{tabular}{|c|c|c|c|c|c|c|}
\hline \multirow{2}{*}{$\begin{array}{c}\text { Локалізація } \\
\text { раку }\end{array}$} & \multicolumn{3}{|c|}{ Основна група (n=38) $(\mathrm{M} \pm \mathrm{m})$ \% } & \multicolumn{3}{|c|}{ Група порівняння (n=53) (M+m)\% } \\
\hline & $\begin{array}{l}\text { верхня } \\
\text { частка }\end{array}$ & $\begin{array}{c}\text { середня } \\
\text { частка }\end{array}$ & $\begin{array}{l}\text { нижня } \\
\text { частка }\end{array}$ & $\begin{array}{l}\text { верхня } \\
\text { частка }\end{array}$ & $\begin{array}{c}\text { середня } \\
\text { частка }\end{array}$ & $\begin{array}{l}\text { нижня } \\
\text { частка }\end{array}$ \\
\hline $\begin{array}{l}\text { Права } \\
\text { легеня }\end{array}$ & $\begin{array}{c}18 \\
(42,1 \pm 1,7)^{*}\end{array}$ & $\begin{array}{c}1 \\
(2,6 \pm 0,8) \%\end{array}$ & $\begin{array}{c}2 \\
(5,2 \pm 0,2)^{*}\end{array}$ & $\begin{array}{c}27 \\
(50,1 \pm 1,8) *\end{array}$ & $\begin{array}{c}2 \\
(3,8 \pm 0,2)^{*}\end{array}$ & $\begin{array}{c}5 \\
(9,4 \pm 0,5)^{*}\end{array}$ \\
\hline Ліва легеня & $\begin{array}{c}13 \\
(31,5 \pm 1,6)^{*}\end{array}$ & - & $4(10,5 \pm 1,8) *$ & $\begin{array}{c}15 \\
(28,3 \pm 1,4)^{*}\end{array}$ & $\begin{array}{c}1 \\
(1,9 \pm 0,9)^{*}\end{array}$ & $\begin{array}{c}3 \\
(5,6 \pm 0,3)^{*}\end{array}$ \\
\hline Усього & $\begin{array}{c}31 \\
(81,6 \pm 1,3)^{*}\end{array}$ & $\begin{array}{c}1 \\
(2,6 \pm 0,8) \%\end{array}$ & $\begin{array}{c}6 \\
(15,8 \pm 2,5)^{*}\end{array}$ & $\begin{array}{c}42 \\
(79,2 \pm 1,1)^{*}\end{array}$ & $\begin{array}{c}3 \\
(5,6 \pm 0,3)^{*}\end{array}$ & $\begin{array}{c}8 \\
(15,1 \pm 2,2)^{*}\end{array}$ \\
\hline $\mathrm{P}$ & & & & & & \\
\hline
\end{tabular}

Примітка. * - рівень значимості в основній і групі порівняння за $\chi^{2}$-критерієм Пірсона $(\mathrm{p}<0,05)$.

12 (31,5 \%) та 19 (35,8 \%), що відображено на рисунках 1 і 2.

В обох групах спостереження переважали хвоpi iз II стадією пухлинного процесу - 28 (73,7 \%) пацієнтів основної та 43 (81,1%) групи порівняння. Пацієнти з III В та IV стадіями дослідженню не підлягали, що відображено в таблиці 3.
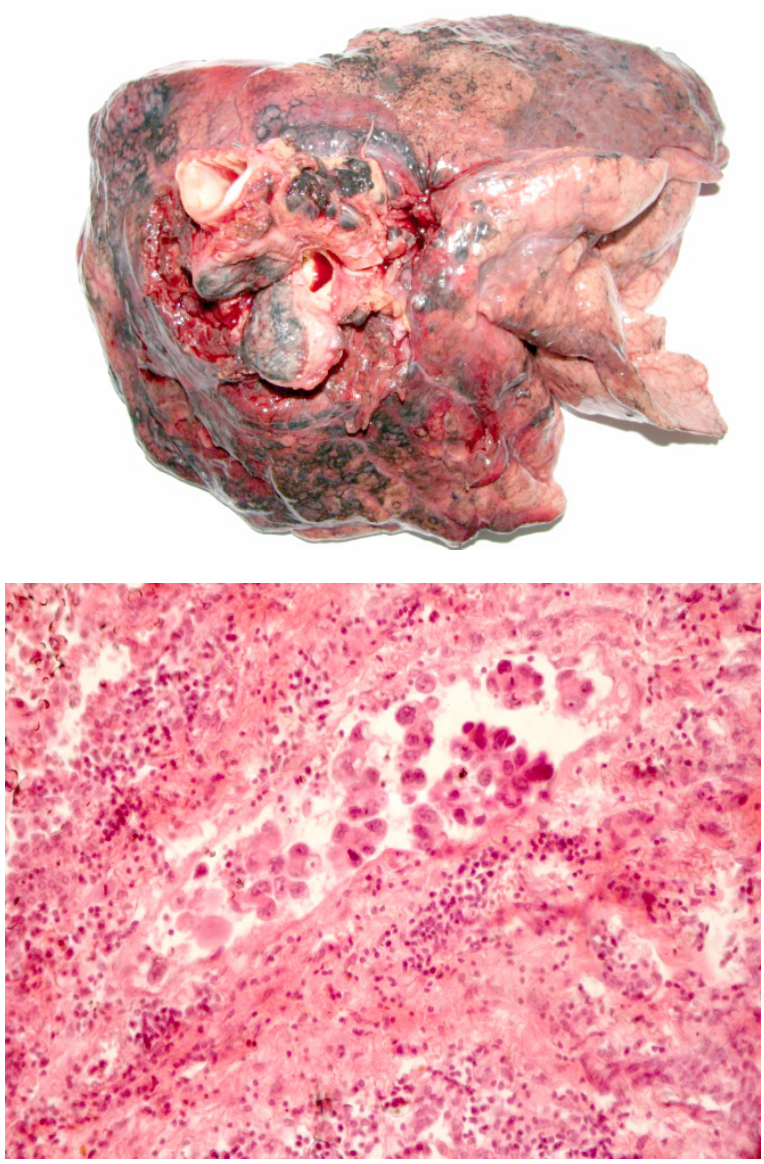

Рис. 1. Макропрепарат центрального (аденокарцинома) раку легені, поєднаний із метатуберкульозом. Гістофотограма аденокарциноми легені на тлі посттуберкульозного фіброзу. Забарвлення гематоксиліном та еозином. $\times 400$
Обидві групи хворих за основними критеріями розповсюдженості, характеру та активності туберкульозного та стадією онкологічного процесів, віком, статтю, функціональними показниками та частотою супутньої патології були репрезентативнs, що наглядно показано в таблиці 4.
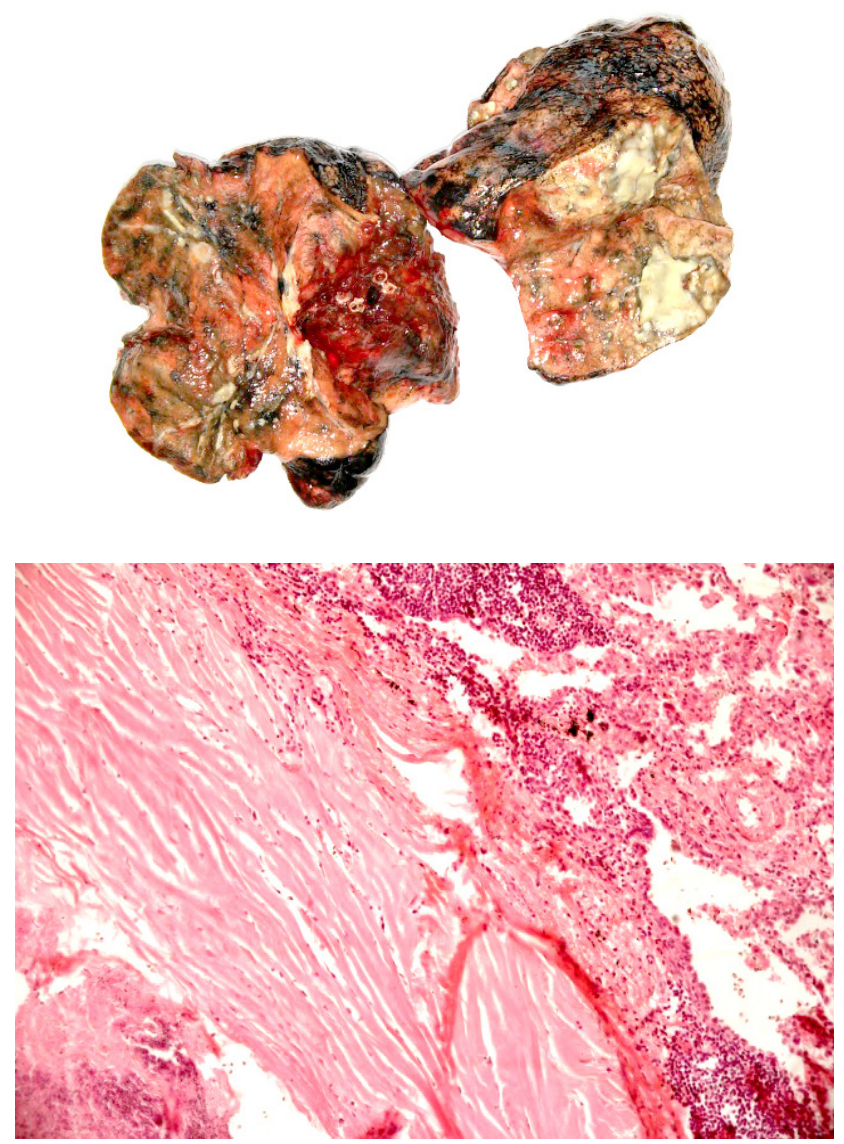

Рис. 2. Макропрепарат периферичного (плоскоклітинного) раку легені в поєднанні з туберкульомою. Гістофотограма плоскоклітинного раку легені в стінці туберкульоми. Забарвлення гематоксиліном та еозином. $\times 200$ 
Таблиця 3. Стадії раку легень у групах спостереження (Mm) \%

\begin{tabular}{|c|c|c|c|}
\hline Стадія раку легені & $\begin{array}{c}\text { Основна група } \\
(\mathrm{n}=38)(\mathrm{M} \pm \mathrm{m}) \%\end{array}$ & $\begin{array}{c}\text { Група порівняння } \\
(\mathrm{n}=53)(\mathrm{M} \pm \mathrm{m}) \%\end{array}$ & $\begin{array}{l}\text { Достовірність } \\
\text { від’ємностей }\end{array}$ \\
\hline IA & $3(7,9 \pm 0,5)^{*}$ & $3(5,7 \pm 0,6)^{*}$ & $\begin{array}{l}x^{2}=0,03 \\
p=0,89\end{array}$ \\
\hline IB & $5(13,2 \pm 2,7)^{*}$ & $4(7,5 \pm 0,4)^{*}$ & $\begin{array}{l}x^{2}=1,03 \\
p=0,19\end{array}$ \\
\hline IIA & $16(42,1+2,2)^{*}$ & $24(45,3 \pm 1,8)^{*}$ & $\begin{array}{l}x^{2}=0,06 \\
p=0,43\end{array}$ \\
\hline IIB & $12(31,5 \pm 2,8)^{*}$ & $19(35,8 \pm 2,2)^{*}$ & $\begin{array}{l}x^{2}=3,83 \\
p=0,21\end{array}$ \\
\hline IIIA & $2(5,3 \pm 0,8)^{*}$ & $3(5,7 \pm 0,8)^{*}$ & $\begin{array}{l}x^{2}=1,85 \\
p=0,47\end{array}$ \\
\hline Усього & 38 (100) & $53(100)$ & \\
\hline
\end{tabular}

Примітка. * - рівень значимості в основній і групі порівняння за $\chi^{2}$-критерієм Пірсона $(\mathrm{p}<0,05)$.

Таблиця 4. Порівняльна характеристика пацієнтів груп спостереження (M+m) \%

\begin{tabular}{|c|c|c|}
\hline Критерії порівняння & $\begin{array}{c}\text { Основна група } \\
(\mathrm{n}=38)(\mathrm{M} \pm \mathrm{m}) \%\end{array}$ & $\begin{array}{c}\text { Група порівняння } \\
(\mathrm{n}=53)(\mathrm{M} \pm \mathrm{m}) \%\end{array}$ \\
\hline Вік 55-65 років & $(84,2 \pm 1,2)$ & $(86,8+1,4)^{*}$ \\
\hline Середній вік (роки) & $(59,0 \pm 1,6)$ & $(61,5 \pm 1,8)^{*}$ \\
\hline $\begin{array}{l}\text { - чоловіки } \\
\text { - жінки }\end{array}$ & $\begin{array}{l}(89,5 \pm 1,8) \\
(10,5 \pm 2,1)\end{array}$ & $\begin{array}{l}(88,7 \pm 1,2)^{*} \\
(11,3 \pm 2,4)^{*}\end{array}$ \\
\hline Середня тривалість захворювання на туберкульоз (роки) & $3,3+0,2$ & $3,7 \pm 0,3 *$ \\
\hline Наявність мікробактерій туберкульозу (МБТ+) & $(39,6+2,2)$ & $(28,3 \pm 1,9)^{*}$ \\
\hline Частота мультирезистентних штамів, наявність МБТ+ & $\begin{array}{c}13,1 \pm 2,1 \\
(39,6 \pm 2,2) \\
\end{array}$ & $\begin{array}{c}15,1 \pm 2,8 * \\
(28,3 \pm 1,9)^{*}\end{array}$ \\
\hline МБТ+ на момент операції & $(29,2 \pm 1,4)$ & $(24,2 \pm 1,5) *$ \\
\hline Частота периферичного раку легень & $(68,4+1,3)$ & $(64,1+1,1)^{*}$ \\
\hline Частота центрального раку легень & $(31,5+2,1)$ & $(35,8 \pm 1,6)^{*}$ \\
\hline Частота супутньої патології & $(42,1 \pm 1,4)$ & $(43,4 \pm 1,9)^{*}$ \\
\hline $\mathrm{P}$ & \multicolumn{2}{|c|}{$\mathrm{p}<0,05$} \\
\hline
\end{tabular}

Примітка. * - рівень значимості за критерієм $\chi^{2}$-Пірсона в основній і групі порівняння $(\mathrm{p}<0,05)$.

За видом та способом проведених хірургічних операцій переважали розширені пневмонектомії. Для статистичної достовірності також була виконана достатня група радикальних лобектомій, правобічних та лівобічних, що відображено в таблиці 5.

У патогістологічних дослідженнях переважали форми аденокарциноми - 24 (63,1%) випадків в основній групі та 40 (75,5 \%) у групі порівняння. Також мали місце різні види плоскоклітинного раку - 12 (31,5 \%) в основній та 12 (22,6 \%) у групі порівняння. Крім того, у 2 випадках (5,2 \%) основної групи та в одному (1,9 \%) групи порівняння вірогідно визначалися інші форми недрібноклітинного раку легень, що наглядно відображено в таблиці 6.

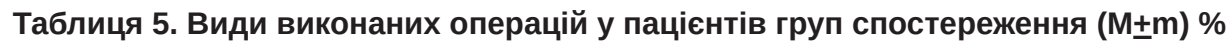

\begin{tabular}{||l|c|c||}
\hline \multicolumn{1}{|c|}{ Вид виконаної операції } & Основна група $(\mathrm{n}=38)(\mathrm{M} \pm \mathrm{m}) \%$ & Група порівняння $(\mathrm{n}=53)(\mathrm{M} \pm \mathrm{m}) \%$ \\
\hline Пневмонектомія & $29(76,3 \pm 1,3)$ & $36(67,9 \pm 1,3)^{*}$ \\
\hline Білобектомія & $1(2,6 \pm 0,3)$ & $2(3,8+0,3)^{*}$ \\
\hline Лобектомія & $8(21,1 \pm 0,3)$ & $15(28,3 \pm 3,3)^{*}$ \\
\hline Усього & $38(100)$ & $53(100)^{*}$ \\
\hline \multicolumn{2}{|c|}{$\mathrm{P}$} & $\mathrm{p}<0,05$ \\
\hline
\end{tabular}

Примітка. * - рівень значимості за $\chi^{2}$-критерієм Пірсона в основній і групі порівняння р<0,05. 
Таблиця 6. Гістологічні фрорми раку легень у групах хворих(M+m) \%

\begin{tabular}{||c|c|c|c||}
\hline $\begin{array}{c}\text { Гістологічна } \\
\text { форма }\end{array}$ & $\begin{array}{c}\text { Основна група } \\
(\mathrm{n}=38)(\mathrm{M} \pm \mathrm{m}) \%\end{array}$ & $\begin{array}{c}\text { Група порівняння } \\
(\mathrm{n}=53)(\mathrm{M} \pm \mathrm{m}) \%\end{array}$ & $\begin{array}{c}\text { Достовірність } \\
\text { від’ємностей }\end{array}$ \\
\hline Аденокарцинома & $24(63,1 \pm 1,7)^{*}$ & $40(75,5 \pm 1,1)^{*}$ & $\begin{array}{c}\mathrm{x}^{2}=0,34 \\
\mathrm{p}=0,12\end{array}$ \\
\hline Плоскоклітинний рак & $12(31,6 \pm 2,7)^{*}$ & $12(22,6 \pm 2,2)^{*}$ & $\begin{array}{c}\mathrm{x}^{2}=0,09 \\
\mathrm{p}=0,13\end{array}$ \\
\hline Інші форми & $2(5,3 \pm 0,6)^{*}$ & $1(1,9 \pm 0,9)^{*}$ & $\begin{array}{c}\mathrm{x}^{2}=0,72 \\
\mathrm{p}=0,26\end{array}$ \\
\hline Усього & $38(100)$ & $53(100)$ & \\
\hline \hline
\end{tabular}

Примітка. * - рівень значимості в основній і групі порівняння за $\chi^{2}$-критерієм Пірсона $(\mathrm{p}<0,05)$.

Проаналізовано морфологічні особливості поєднаних форм легеневого туберкульозу та недрібноклітинного раку легень у групах порівняння, які досліджували ретроспективно. Ми провели розподіл клінічних випадків НДКРЛ на групи за ознакою активності та форми туберкульозного процесу. Рак на тлі туберкульозних змін та рак у рубці ми встановили у 81,6 \% випадків. Рак в активній туберкульомі - у 7,8 \% випадків та у 10,5 \% було виникнення ракової пухлини в стінці фіброзної каверни, що відображено в таблиці 7.
Метастазування раку мало місце найчастіше в тих лімфатичних вузлах, морфологічна структура яких не була грубо порушена туберкульозними ураженнями. Навпаки, значні фіброзно-склеротичні зміни значно перешкоджали метастазуванню. При цьому в 23,5 \% випадків мало місце порушення поступовості метастатичного ураження лімфатичних вузлів кореня легені та середостіння і поява так-званих “стрибаючих метастазів” при поєднаних формах. Разом з тим, у пацієнтів, яких прооперовано з приводу раку легень без туберку-

Таблиця 7. Морфологічні особливості поєднаних форм туберкульозу та раку легень у пацієнтів обох груп спостереження $(\mathrm{M} \pm \mathrm{m}) \%$

\begin{tabular}{|c|c|c|c|c|}
\hline \multirow{2}{*}{ Морфологічна форма } & \multicolumn{2}{|c|}{ Основна група $(\mathrm{n}=38)(\mathrm{M} \pm \mathrm{m}) \%$} & \multicolumn{2}{|c|}{ Група порівняння $(\mathrm{n}=53)(\mathrm{M} \pm \mathrm{m})$ \% } \\
\hline & абс. & $\%$ & абс. & $\%$ \\
\hline Рак в пост-туберкульозних змінах: & 31 & $81,6+2,6 *$ & 46 & $86,7 \pm 1,8 *$ \\
\hline -фіброз; & 4 & $10,5 \pm 2,2 *$ & 6 & $11,3 \pm 2,7 *$ \\
\hline - цироз; & 3 & $7,8 \pm 0,1^{*}$ & 4 & $7,5 \pm 0,6 *$ \\
\hline - щільні вогнища; & 6 & $15,7 \pm 1,0 *$ & 8 & $15,1 \pm 3,2 *$ \\
\hline -конгломерати вогнищ; & 5 & $13,1+3,6^{*}$ & 7 & $13,2+3,2 *$ \\
\hline - неактивні туберкульози & 8 & $21,0 \pm 5,2 *$ & 11 & $20,7 \pm 2,4 *$ \\
\hline - сановані каверни & 5 & $13,1 \pm 2,9 *$ & 10 & $18,8 \pm 3,9 *$ \\
\hline Рак в активній туберкульомі & 3 & $7,8+2,1 *$ & 4 & $7,5+2,3 *$ \\
\hline Рак у стінці каверни & 4 & $10,5+2,6 *$ & 3 & $5,6+1,8 *$ \\
\hline $\mathrm{P}$ & \multicolumn{4}{|c|}{$\mathrm{p}<0,05$} \\
\hline
\end{tabular}

Примітка. * - рівень значимості за $\chi^{2}$-критерієм Пірсона в основній та групі порівняння $(\mathrm{p}<0,05)$.

Таблиця 8. Особливості метастатичного ураження при поєднаних формах туберкульозу і раку легень у групах спостереження

\begin{tabular}{||c|c|c|c||}
\hline \multirow{2}{*}{\multicolumn{1}{|c|}{ Група хворих }} & \multicolumn{3}{|c||}{ Наявність метастатичного ураження } \\
\cline { 2 - 4 } & $\begin{array}{c}\text { у лімфовузли } \\
\text { кореня легені (N1) }\end{array}$ & $\begin{array}{c}\text { у лімфовузли кореня } \\
\text { легені та лімфовузли } \\
\text { середостіння (N2) }\end{array}$ & $\begin{array}{c}\text { у лімфовузли середостіння } \\
\text { без ураження лімфовузлів } \\
\text { кореня }\end{array}$ \\
\hline $\begin{array}{l}\text { Поєднані форми раку та } \\
\text { туберкульозу легень (n=17) }\end{array}$ & $9(52,9 \pm 1,7)$ & $4(23,5 \pm 2,2)$ & 4 (23,5,4) \% \\
\hline Рак легень $(\mathrm{n}=15)$ & $7(46,6 \pm 2,1)$ & $8(53,3 \pm 1,3)$ & 0 \\
\hline \hline
\end{tabular}

Примітка. * - рівень значимості в основній і групі порівняння за $x^{2}$-критерієм Пірсона $(\mathrm{p}<0,05)$. 
льозу, таких “стрибаючих метастазів” ми не виявили, що відображено в таблиці 8.

При вивченні впливу туберкульозу на оперативне лікування хворих із поєднаними формами туберкульозу та раку легень у групі порівняння з'ясували, що плевральна порожнина була повністю облітерована у 10,2 \% хворих та частково облітерована у 17,2 \%. В 47,6 \% випадків спостерігалися множинні плевральні зрощення. В 75 \% випадків для виділення легені зі зрощень застосовувався екстраплевральний пневмоліз. В 11,3 \% випадків наявність в плевральній порожнині вираженого злукового процесу та тяжкого виділення легені із зрощень призводило до інтраопераційної кровотечі. Туберкульоз легень у 9,4 \% хворих був причиною для розширення об'єму оперативного втручання до пневмонектомії. Висока частота (7,5 \%) внутрішньоплевральних кровотеч зумовлювалася необхідністю проведення екстраплеврального пневмолізу під час підходу до кореня легені, а також рубцевими та казеозними змінами в лімфовузлах кореня легені та середостінні. Наявність фіброзно-склеротичної метатуберкульозної трансформації перибронхіальної клітковини становило технічні труднощі під час формування кукси головного бронха. Неспроможність кукси головного бронха у хворих групи порівняння спостерігали у 7,5 \%. При ретроспективному аналізі 53 операцій (17 лобектомій та 36 пневмонектомій) у хворих із поєднаними формами туберкульозу та раку легень привертає на себе увагу висока питома вага інтраопераційних (22,6 \%) та післяопераційних ускладнень $(28,4$ \%) при виконанні оперативних втручань із використанням стандартної бокової торакотомії.

3 метою ранньої діагностики легеневого туберкульозу та раку ми вдосконалили відомий спосіб шляхом використання спіральної КТ з внутрішньовенним контрастним підсиленням. Для цього використовували систематизований алгоритм із застосуванням мультипланарних реконструкцій, реконструкцій МІР для кращої візуалізації мікронодулярних змін, Mini Р для кращої візуалізації трахеобронхіального дерева, та 3 D-реконструкцій для об’ємного вивчення патології. За допомогою систематизованого алгоритму вивчення променевої КТ - семіотики та аналізу денсотометричних показників, різниці щільностей уражень нативно та після контрастного підсилення дозволило провести диференційний аналіз пухлинних та туберкульозних змін або їх поєднання.

У 32 досліджуваних пацієнтів перед хірургічним втручанням використовували торакоскопію 3 відеопідтримкою (VATS) з метою проведення біопсії та оцінки метастатичного ураження лімфа- тичних вузлів кореня та середостіння. Отримані дані показали перевагу міні-інвазивних методів діагностики в оцінці метастатичного ураження лімфовузлів середостіння, а саме уточнення стадії за статусом N0; N1-2 при НДКРЛ. Використання розробленого нами диференційно-діагностичного алгоритму дозволило покращити ранню діагностику раку легень у хворих із легеневим туберкульозом з можливістю більш раннього їхнього хірургічного лікування, що відображено на рисунку 2.

3 використанням стерномедіастинального доступу ми прооперували 38 хворих із поєднаними формами туберкульозу та раку легень. 9 особам виконано лобектомію, 29 - пневмонектомію. У цілому в 25,4 \% наших спостережень ступінь поширення пухлинного процесу був перебільшений. Використання стерномедіастинального доступу дало можливість точніше визначити межу переходу пухлини на сусідні анатомічні структури і виконати заплановану радикальну операцію. Коли лімфатичні вузли кореня легені та межистіння зрощені з бронхами, а пухлина перибронхіально та перивазально інтимно прилягає або зрощена 3 утвореннями середостіння, ми розробили методику розширеної лобектомії та пневмонектомії з використанням стерномедіастинального доступу. Застосування стерномедіастинального доступу при виконанні розширених резекцій у хворих із поєднаними формами туберкульозу та раку легень дозволило виконати втручання на середостінні до видалення препарату, що відповідає принципу онкологічного радикалізму, абластики та забезпечує доступність та повноту виконання білатеральної лімфодисекції. Це також значно зменшило обсяг інтраопераційної кровотечі шляхом реалізації ретроградної схеми резекції об'ємного процесу в обхід плевральним зрощенням. При порівняльному аналізі частоти та характеру інтраопераційних ускладнень встановлено, що в цілому в основній групі вони зустрічалися у 2,1 раза вірогідно рідше, ніж у групі порівняння $(\mathrm{p}<0,05)$. Інтраопераційні ускладнення у хворих основної групи трапляються у $(13,2+2,6) \%$, тоді як у групі порівняння - у $(22,6 \pm 4,2) \%$ випадків. Основними видами інтраопераційних ускладнень хворих основної групи було розкриття контрлатеральної плевральної порожнини та порушення серцевого ритму. Серед інтраопераційних ускладнень у групі порівняння найбільш загрозливим було пошкодження судин кореня легені в анатомічних умовах, охоплених фіброзно-склеротичними метатуберкульозними змінами, а також при видаленні конгломератів лімфатичних вузлів від магістральних судин. Інтраопераційна кровотеча у хворих основної групи 


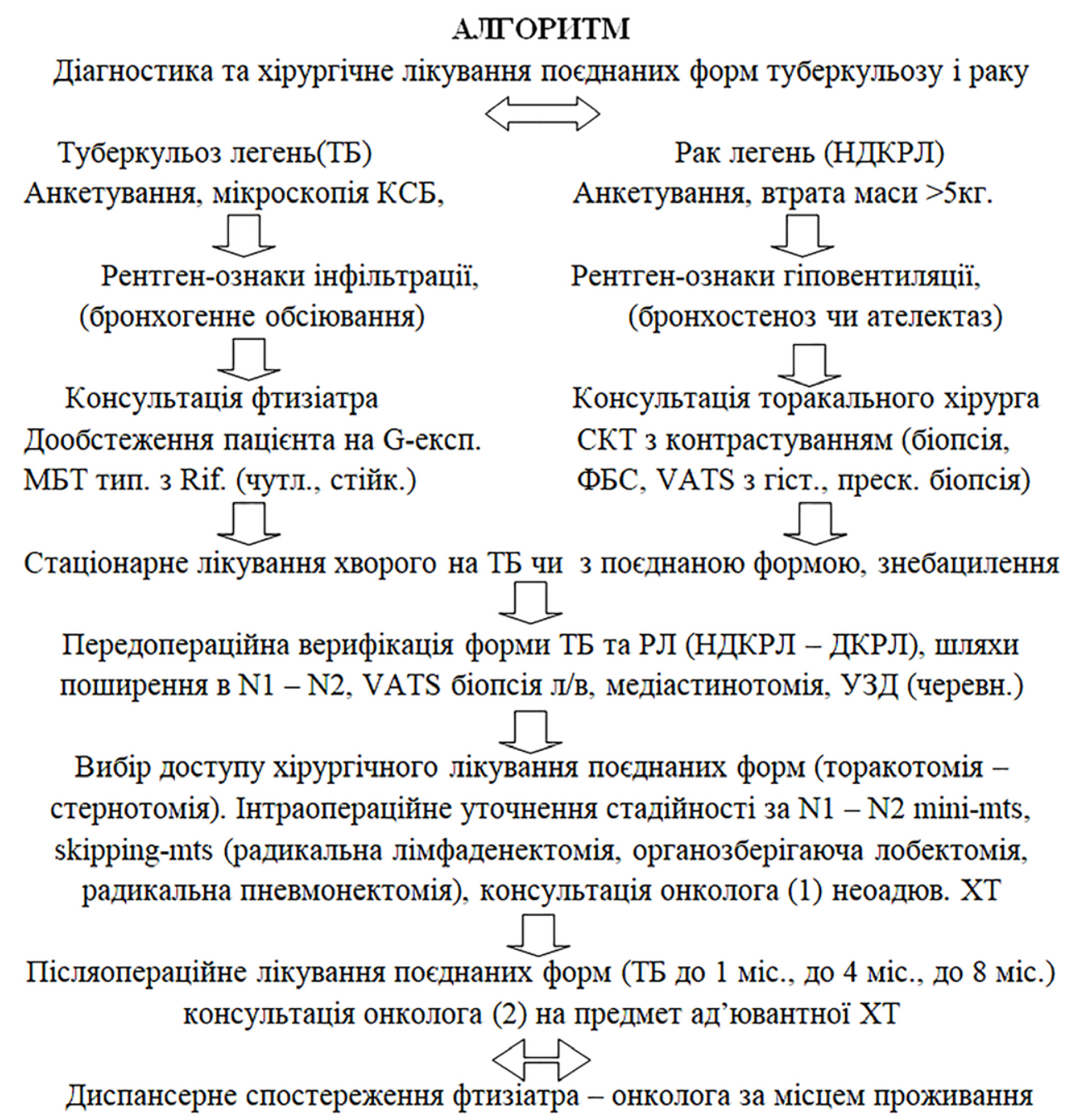

Рис. 2. Переопераційний алгоритм діагностики та хірургічного лікування поєднаних форм туберкульозу і раку легень.

в середньому складала $(542,5+44,8)$ мл, тоді як у хворих групи порівняння $(822,3 \pm 21,7)$ \% мл (у 1,5 раза більше). Зменшення крововтрати при виконанні операції з стерно-медіастинального доступу досягається за рахунок перев'язки легеневих артерій (часткових або головних) без попереднього виділення легені із зрощень. Частота післяопераційних ускладнень у групі порівняння була у 1,5 раза вірогідно вище, ніж у хворих основної групи. Емпієма плеври з бронхіальною норицею у післяопераційному періоді вірогідно рідше у 3,2 раза $(\mathrm{p}<0,05)$ трапляється у групі хворих, що перенесли пневмонектомію із стерномедіастинального доступу. Це пояснюється можливістю створення максимально короткої кукси головного бронху незалежно від сторони операції з пластичним її укриттям зв'язками середостіння. В ранньому післяопераційному періоді у хворих основної групи спостерігалося 7 ускладнень: повільне розправлення легені (1), пневмонія оперованої легені (1), емпієма плеври з бронхіальною норицею (1), внутрішньоплевральна кровотеча (1), легенево-серцева недостатність (2), тромбоемболія легеневих артерій (1). При цьому найбільша кількість ускладнень (57 \%) зафіксована у хворих з супутнім активним туберкульозом, що відображено в таблиці 9.

Таким чином, клінічний ефект у найближчому післяопераційному періоді досягнуто у 94,7 \% оперованих пацієнтів основної групи. У групі порівняння найближчий клінічний ефект відмічено у 80,5 \%. У хворих із поєднаними формами туберкульозу та раку легень із метою полегшення операційно-технічного етапу та підвищення радикальності хірургічного втручання ми розробили та використовували методики лобектомії та пневмонектомії із білатеральною медіастинальною лімфодисекцією зі стерномедіастинального доступу. Порівняльний аналіз у групах хворих показав, що інтраопераційні ускладнення в таких випадках бувають у 2,1 рази вірогідно рідше, ніж 


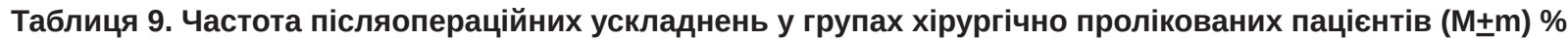

\begin{tabular}{|c|c|c|}
\hline Характер ускладнень & Основна група $(\mathrm{n}=38)(\mathrm{M} \pm \mathrm{m}) \%$ & Група порівняння $(\mathrm{n}=53)(\mathrm{M} \pm \mathrm{m}) \%$ \\
\hline \multicolumn{3}{|c|}{ Лобектомії (n=9) } \\
\hline Пневмонія оперованої легені & $1(11,1 \pm 1,2)^{*}$ & $2(11,7 \pm 1,4)^{*}$ \\
\hline Повільне розправлення легені & $1(11,1 \pm 1,2)^{*}$ & $2(11,7 \pm 1,4)^{*}$ \\
\hline \multicolumn{3}{|c|}{ Пневмонектомії (n=65) } \\
\hline Характер ускладнень & Основна група $(\mathrm{n}=29)$ & Група порівняння (n=36) \\
\hline Емпієма плеври з бронхіальною норицею & $1(3,9 \pm 0,8)^{*}$ & $4(11,1 \pm 1,3)^{*}$ \\
\hline Внутрішньоплевральна кровотеча & $1(3,9 \pm 0,8) *$ & $4(11,1+1,3)^{*}$ \\
\hline Гостра серцева недостатність & $2(6,8 \pm 0,9)^{*}$ & $1(2,8 \pm 0,6)^{*}$ \\
\hline Тромбоз легеневої артерії & $1(3,9 \pm 0,8)^{*}$ & $1(2,8 \pm 0,6)^{*}$ \\
\hline Усього ускладнень & $7(18,4 \pm 1,7)^{*}$ & $14(28,4 \pm 1,6)^{*}$ \\
\hline Померло & $1(2,6 \pm 0,3)^{*}$ & $2(3,8 \pm 0,8)^{*}$ \\
\hline
\end{tabular}

Примітка. ${ }^{\star}$ - рівень значимості в основній і групі порівняння за $\chi^{2}$-критерієм Пірсона $(\mathrm{p}<0,05)$.

у групі порівняння $(\mathrm{p}<0,05)$. Це пов'язано зі створенням сприятливих операційних умов для обробки судин та бронхів кореня легені в анатомічних умовах, що не охоплені метатуберкульозними та посттуберкульозними змінами. Отже, пацієнтам із поєднаними формами туберкульозу з недрібноклітинною формою раку легень при підозрі на “стрибаючі метастази” ми рекомендуємо проводити операції із стернотомічного хірургічного доступу із повною системною білатеральною лімфаденектомією та наступною радикальною резекцією патологічно зміненої легені. Віддалені результати хірургічного лікування пацієнтів із поєднаними формами відображено в таблиці 10.

Таблиця 10. Віддалені результати хірургічного лікування пацієнтів із поєднаними фрормами обох груп спостереження $(\mathrm{M} \pm \mathrm{m}) \%$

\begin{tabular}{|c|c|c|}
\hline Критерії ефективності & Основна група & Група порівняння \\
\hline Місцеві рецидиви (\%) & $10,2 \pm 1,8^{*}$ & $23,4 \pm 3,7 *$ \\
\hline Середня тривалість життя (місяці) & $48,6 \pm 4,7 *$ & $37,4 \pm 5,2 *$ \\
\hline Реактивація туберкульозу (\%) & $7,3 \pm 0,2 *$ & $9,4 \pm 0,6 *$ \\
\hline $\begin{array}{l}\text { Летальність від прогресування туберкульозного } \\
\text { процесу (\%) }\end{array}$ & $4,1+0,7 *$ & $4,3 \pm 0,8 *$ \\
\hline $\mathrm{P}$ & \multicolumn{2}{|c|}{$\mathrm{p}<0,05$} \\
\hline
\end{tabular}

Примітка. *- достовірна різниця між групами за ANOVA $(\mathrm{p}<0,05)$.

Висновки. 1. Показано провідний вплив легеневого туберкульозу на операційне лікування хворих із поєднаними формами туберкульозу та раку легень у групах порівняння.

2. Розробка методик резекції легені та повної білатеральної лімфаденектомії із стерно-медіастинального доступу дозволило зменшити інтраопераційні ускладнення з 22,6 до 13,2 \%, післяопераційні ускладнення - 328,4 до 18,4 \%, а частоту емпієми плеври - 3 11,1 до 3,9 \%.

\section{СПИСОК ЛІТЕРАТУРИ}

1. Радионов Б. В. Стернотомия : монография / Б. В. Радионов, Ю. Ф. Савенков. - Днепропетровск : РИА “Днепр-VAL”, 2003. - 308 c.

2. Радикальные операции на главных бронхах у больных с культевыми свищами: монография / Б. В. Радионов,
3. Встановлено збільшення трирічної виживаності у пацієнтів основної групи з 37,4 до 48,6 міс. та зменшення кількості місцевих рецидивів з 23,4 до 10,2 \% випадків за рахунок більш радикальної повної білатеральної лімфадесекції в межистінні.

4. 3 метою профілактики розвитку раку легень усім пацієнтам із середніми та великими залишковими змінами перенесеного легеневого туберкульозу слід призначати радикальне хірургічне лікування з патогістологічними дослідженнями.

Ю. Ф. Савенков, В. М. Мельник, И. Н. Калабуха. - Днепропетровск : РИА “Днепр-VAL”, 2004. - 206 с.

3. Руководство по хирургии туберкулеза легких : монографія / Б. В. Радионов, Ю. Ф. Савенков, И. Н. Калабуха, О. В. Хмель. - Днепропетровск : РИА “Днепр-VAL”, 2012. - 334 с. 
4. Increased lung cancer risk among patients with pulmonary tuberculosis: a population cohort study / Y. H. Yun, C. C. Liao, W. H. Hsu [et al.] // J. Thorac. Oncol. - 2011. - No. 6. - P. 32-37. 5. International Association for the Study of Lung Cancer / W. Travis, E. Brambilla, M. Noguchi [et al.] American Thoracic Sosiety. Eropean Respiratory Society International Vultidisciplinary Classification of Lung Adenocarcinoma // S. Thoracic Oncology. - 2015. - No. 6. - P. 244-285.

6. Pulmonary tuberculosis increases the risk of lung cancer / C. Wu, H. Hu, C. Pu [et al.] // Cancer. - 2011. - No. 117. - P. 618-624.

7. Change in demographic picture and increase of drug resistance in pulmonary tuberculosis in a 10-year interval in Taiwan / T. C. Tsao // Infection. - 2016. - Vol. 30, No. 2. - P. 75-80.

8. Tuberculosis and risk of cancer: a Danish nationwide cohort study / D. F. Simonsen, D. K. Farkas, M. Segaard [et al.] // Int. J. Tuberc. Lung Dis. - 2014. - Vol. 18 (10). - P. 1211-1219.

9. Surgical treatment of lung carcinoma in tuberculosis patients / V. Vencevicius // Medicina (Kaunas). - 2014. - Vol. 40, No. 12.

\section{REFERENCES}

1. Radionov, B.V. \& Savenkov, Yu.F. (2002). Sternotomiya: Monografiya [Sternotomy Monograph]. Dnepropetrovsk: RIA "Dnepr-VAL" [in Russian].

2. Radionov. B.V., Savenkov.Yu.F., Melnik. V.M. \& Kalabucha. I.A. (2004). Radikalni operatsii na glavnikh bronkhakh $v$ bolnikh s kultivemi svishchami: Monografiya [Radical operations on mane bronches in patients with bronchial bursa Monograph]. Dnepropetrovsk: RIA “Dnepr-VAL” [in Russian].

3. Radionov, B.V., Savenkov, Yu.F., Kalabucha, I.A. \& Khmel, O.V. (2012). Rukovodstvo po khirurgii tuberkulosa legkih: Monografiya [Surgery of lung tuberculosis: Monograph]. Dnepropetrovsk: RIA “Dnepr-VAL” [in Russian].

4. Yun, Y.H., Liao, C.C., Hsu, W.H. (2011). Increased lung cancer risk among patients with pulmonary tuberculosis: a population cohort study. J. Thorac. Oncol. 6, 32-37.

5. Travis, W., Brambilla, E., \& Noguchi, M. (2015). International Association for the Study of Lung Cancer: American Thoracic Sosiety, Eropean Respiratory Society, International Vultidisciplinary Classification of Lung Adenocarcinoma. S. Thoracic Oncology, 6, 244-285.

6. Wu, C., Hu, H., \& Pu, C. (2011). Pulmonary tuberculosis increases the risk of lung cancer. Cancer, 117, 618-624.

7. Tsao, T.C. (2016). Change in demographic picture and
- P. 1170-1174.

10. Tuberculosis and cancer: a complex and dangerous lesions / S. Vento, M. Lanzafame // Lancet Oncol. - 2011. - No. 12. P. 520-522.

11. Videoassisted toracoscopic surgery is more favorable than thoracotomy for resection of clinical stage 1 nonsmall cell lung cancer / B. A. Whitson, R. S. Anrade, A. Boettcher [et al.] // Ann. Thorac. Surg. - 2017. - Vol. 83. - P. 1965-1970.

12. The diagnostic value of mediastinoscopy and its application in staging for lung cancer / X. Wang // Zhonghua Zhong Liu Sasshi. - 2015. - Vol. 24, No. 1. - P. 74-76.

13. Two cases of multiple primary cancer involving the lung with old pulmonary tuberculosis / R. Shirai // Nihon okyuki Gakkai Zasshi. - 2014. - Vol. 38, No. 3. - P. 211-216.

14. Cooccurrence of pulmonary tuberculosis and carcinoma: diagnosis and the prognostic factors for surgical effects / B. X. Xie // Zhonghua Jie He He Hu Xi Za Zhi. - 2015. - Vol. 28, No. 4. - P. 230-232.

increase of drug resistance in pulmonary tuberculosis in a 10-year interval in Taiwan. Infection, 30. 2. 75-80.

8. Simonsen, D.F., Farkas, D.K., \& Segaard, M. (2014). Tuberculosis and risk of cancer: a Danish nationwide cohort study. Int. J. Tuberc. Lung Dis., 18 (10), 1211-1219.

9. Vencevicius, V. (2014). Surgical treatment of lung carcinoma in tuberculosis patients. Medicina (Kaunas), 40, 12, 1170-1174.

10. Vento, S.M. \& Lanzafame, M. (2011) Tuberculosis and cancer: a complex and dangerous lesions. Lancet Oncol. 12, 520522.

11. Whitson, B.A., Anrade, R.S., \& Boettcher, A. (2017). Videoassisted toracoscopic surgery is more favorable than thoracotomy for resection of clinical stage 1 non-small cell lung cancer. Ann. Thorac. Surg., 83, 1965-1970.

12. Wang, X. (2015). The diagnostic value of mediastinoscopy and its application in staging for lung cancer. Zhonghua Zhong Liu Sasshi, 24, 1, 74-76.

13. Shirai, R. (2014). Two cases of multiple primary cancer involving the lung with old pulmonary tuberculosis. Nihon okyuki Gakkai Zasshi. 38, 211-216.

14. Xie, B.X. (2015) Cooccurrence of pulmonary tuberculosis and carcinoma: diagnosis and the prognostic factors for surgical effects. Zhonghua Jie He He Hu Xi Za Zhi, 28 (4), 230-232.

Електронна адреса для листування: koshak.yuriy@gmail.com

\section{YU. F. KOSHAK ${ }^{1}$, YU. F. SAVENKOV 2}

I. Horbachevsky Ternopil State Medical University ${ }^{1}$

Ternopil Regional TB Hospital ${ }^{1}$

Dnipropetrovsk Regional Council of Clinical and Preventive Medicine "Phthisiology", Dnipro²

\section{DIAGNOSIS AND SURGICAL TREATMENT OF PATIENTS WITH COMBINED FORMS OF TUBERCULOSIS AND LUNG CANCER}

The aim of the work: to raise efficiency of the surgical treatment of patients with combined forms of pulmonary tuberculosis and non-small cell lung cancer. 
Materials and Methods. The retrospective analysis was conducted to 91 patient with combined forms of pulmonary tuberculosis and lung cancer, who were treated in TB hospitals, surgical departments of different regions of Ukraine.

Results and Discussion. The analysis of the morphological features of combined forms of pulmonary tuberculosis and non-small cell lung cancer was made in comparison groups, that were explored retrospectively.

The leading effect of pulmonary tuberculosis on the surgical treatment of patients with combined forms of tuberculosis and lung cancer was shown in groups of comparison. The increase of 3 years survival in patients of basic groups is set, demonstrating the advantage of active surgical tactics of sterno-mediastinal access and the appliance of more radical bilateral lymph node dissection.

Key words: pulmonary tuberculosis; combined forms of TB with non-small cell lung cancer, diagnostics; surgical treatment; sternomediastinal access; radical bilateral lymph node dissection.

Ю. Ф. КОШАК ${ }^{1}$, Ю. Ф. САВЕНКОВ ${ }^{2}$

ГВУз “Тернопольский государственный медицинский университет имени И. Я. Горбачевского МЗ Украины” КУ “Тернопольский областной противотуберкулезный диспансер"

КУ “Днепропетровское областное коммунальное клиническое лечебно-профилактическое объединие “Фтизиатрия" ДоС”, Днепр

\section{ДИАГНОСТИКА И ХИРУРГИЧЕСКОЕ ЛЕЧЕНИЕ ПАЦИЕНТОВ С КОМБИНИРОВАННЫМИ ФОРМАМИ ТУБЕРКУЛЕЗА И РАКА.ЛЕГКИХ}

Цель работы: впервые в Украине представить первый анализ эффективной ранней диагностики и хирургического лечения больных комбинироваными формами легочного туберкулеза и немелкоклеточного рака легких с использованием стерномедиастинального хирургического доступа; повысить эффективность хирургического лечения больных с комбинированными формами туберкулеза и немелкоклеточного рака легких.

Материалы и методы. Проведена выборка пациентов, ретроспективный анализ 91 случая больных с комбинированными формами легочного туберкулеза и рака легких в противотуберкулезных диспансерах, хирургических отделениях различных регионов Украины.

Результаты исследований и их обсуждение. Проанализовано морфологические особенности комбинированных форм туберкулеза, асоциированного с немелкоклеточной формой рака легких в группах сравнения, которые исследовались ретроспективно. Показано ведущее влияние легочного туберкулеза на хирургическое лечение у больных с комбинированными формами туберкулеза и рака легких в группах сравнения. Установлено увеличение трехлетней выживаемости у пациентов основной группы, что свидетельствует в пользу активной ранней диагностики, хирургической тактики стерно-медиастинального доступа и использования при этом более радикальной системной полной билатеральной лимфодисекции в средостении.

Ключевые слова: комбинированные формы туберкулеза и немелкоклеточного рака легких; диагностика; хирургическое лечение; стерно-медиастинальный доступ; полная билатеральная лимфодиссекция в средостении. 